\title{
Gladkovska V. \\ SUBSTANTIATION OF THE DEVELOPMENT VARIANT OF FREIGHT FORWARDING COMPANY UNDER UNCERTAINTY CONDITIONS
}

Ідентифіковано фактори невизначеності в діяльності транспортно-експедиторських компаній. Встановлено поетапна трансформація невизначеності в процесі реалізації заходів з розвитку. Існуючий метод вибору в нечітких умовах адаптований для обгрунтування варіанту розвитку транспортно-експедиторської компанії. Встановлено безліч критерїв вибору варіанта розвитку. Представлені експериментальні розрахунки по вибору варіанту розвитку комплексу послуг транспортно-експедиторської компанії.

Ключові слова: теорія нечітких множин, фактори невизначеності, розвиток комплексу послуг транспортно-експедиторської компанії.

\section{Introduction}

The current work and development of freight forwarding companies is carried out under uncertainty conditions.

At the same time, if in the process of providing services the freight forwarding company is in conditions of probabilistic uncertainty, then in the development processes the uncertainty is less predictable. Therefore, in order to justify the direction of the development of a freight forwarding company, methods are needed that would take this situation into account.

Despite the multiple appeal of scientific research [1-3] to the problem of the development of freight forwarding services, most of them do not provide methods, models, tools, algorithms, etc., which justify the direction of development of freight forwarding services. There is also no possibility to quantify the parameters of the specified development process, therefore, the appeal to this problem is topical.

\section{The object of research and its technological audit}

The object of research is the rationale for development of a freight forwarding company.

According to [1], the development of a freight forwarding company can be carried out in the following aggregated directions:

- freight forwarding (mono-business);

- diversified business;

- transformation into a logistics operator.

A variety of alternative development options is established in three stages.

First step. Aggregated areas of «diversified business» and «logistics operator» are divided into sub-directions, taking into account the specification. For example, in the category of «logistics operator», the services of a road carrier, warehouse services, which can also be detailed, are allocated.
Second step. For each aggregated direction (sub-direction) in accordance with the Ansoff matrix [2], functional development options are formed:

- new direction - gaining market share;

- existing direction is an increase in the volume of services or access to new segments in terms of cargo and coverage geography.

Thus, a «template» of development is formed, and in the third stage potential variants are formed for this template (at the content level). For example, if take an entry into a new market in terms of cargo, it depends on the type of cargo (cargo A, cargo B, cargo C), etc.

Further, it is necessary to study the remaining options, and on the basis of feasibility studies, many quantitative and qualitative characteristics of each option are formed.

As a result, let's obtain a lot of alternative options for development of the freight forwarding company and their main characteristics.

Further, there arises the need for a multicriteria analysis of these development options and the rationale for choosing the most expedient from the viewpoint of multiple goals.

Such task should be solved taking into account the uncertainty of the conditions of choice and the further implementation of the development option. To date, this task has not been solved for freight forwarding companies.

\section{The aim and objectives of research}

The aim of research is justification of the development of a freight forwarding company under uncertainty conditions.

To achieve this aim, it is necessary to perform the following tasks:

1. To identify the uncertainties in the development of a freight forwarding company.

2. To develop a method for selecting the development option for a freight forwarding company from a variety of alternatives, taking into account uncertainty.

3. To perform an experimental verification of the developed method. 


\section{Research of existing solutions of the problem}

Development of companies [3-6], including those working in the transport sector, has been devoted to a significant number of works, for example [7-10].

Contents, functions and main trends in development of freight forwarding services are presented in the studies [11-14].

It should be noted publications [13, 14], which are devoted to one of the aspects of the development of freight forwarding services, namely, justification of feasibility, assessment of the scope of possible work and risks when working in a new market. In these studies, a quantitative assessment of the possible amount of work and their deviation as a measure of risk is given.

The main results of development of freight forwarding companies in [11] are proposed: competitiveness level of the company, competitiveness level of individual services of the company, profit level, market share or the number of serviced goods.

The set of used indicators is primarily determined by the goals and essence of development. If the goal is increasing the competitiveness of the company, the main indicators are the level of competitiveness of individual services and the company as a whole, and the market share and profit level are the complement necessary for an adequate evaluation of the results. So, if the increase in competitiveness is observed against the background of a decline in profit, this situation causes the need for certain measures aimed at changing it. Therefore, let's believe that the result of development should be characterized by a comprehensive assessment, on the basis of which a criterion or set of criteria is used, which is used to select the development option from a variety of alternatives.

Special attention has been given to this issue in the special literature, including methods for calculating integral indicators $[15,16]$, usually based on the procedures for setting and assigning weights for a system of indicators (criteria). But such results are focused on a high level of certainty of information. For situations of uncertainty, most publications propose to use a system of criteria for making decisions using one of the criteria (Hurwitz, Savage, etc.) [15].

\section{Methods of research}

One of the mathematical apparatus that allows one to formalize various descriptions under uncertainty is the theory of fuzzy sets [16, 17]. In [18], a method of multi-criteria choice based on the theory of fuzzy sets is proposed, which can be adapted to select the development option for a freight forwarding company. This method is a synthesis of descriptions of criteria using fuzzy sets and Saaty pairwise comparison method.

\section{Research results}

6.1. Identification and characterization of uncertainties in the development of a freight forwarding company. Let's determine the uncertainty factors and the result of their impact on the development processes of freight forwarding companies.
Let's believe that the result of the development of a freight forwarding company should be described by the following indicators:

- competitiveness level of the company;

- competitiveness level of individual services of the company;

- profit level (in general for the company and separately for each line of business);

- market share (for each line of business) or the number of serviced cargo.

Regardless of what is chosen as a development criterion, the main characteristic of the development results of a freight forwarding company is the volume of cargo serviced.

It determines the market share, the profit level, and also is formed under the influence of competitiveness and simultaneously determines it (the higher the volume of cargo serviced - the higher the competitiveness, and vice versa). Increased competitiveness, due to various factors, positively affects the attraction of customers and, as a consequence, the volume of serviced cargo.

The basis for the various criteria for development of the freight forwarding company is the volume of serviced cargo. Also, the effectiveness of the implementation of various development activities depends on the pricing policy of the company and the subjects of the competitive environment, which ultimately manifests itself in the effectiveness of the activity.

The main factors of uncertainty when deciding on the development of a freight forwarding company are the potential volumes of cargo for servicing, which are formed (Fig. 1) under the influence of a competitive environment, volumes of foreign trade cargo and the state of the transport system.

Efficiency is the second most important factor of uncertainty, forming together with the volumes of serviced cargo the final results of the work of the freight forwarding company.

It should be noted that when implementing planned measures to develop the company, uncertainty manifests itself in three directions (Fig. 1):

1) uncertainty of information and knowledge about the current state of the transport services market and the company. Even if the company tracks the activities of competitors, cargo owners' demand, etc., this information is not complete and reliable, because it is practically impossible to fully and reliably inform about something in the transport market;

2) uncertainty of the future state of the external environment, which is impossible to describe fully and reliably because of the large volume of influencing factors and the practical impossibility of their reliable foresight;

3) uncertainty of the conditions for the implementation of development activities (the reasons are similar to paragraphs 1,2).

According to experts, the longer the planning horizon, the less reliable the information, and conversely, as the planning horizon decreases, the degree of uncertainty decreases.

Therefore, development of development activities should be carried out in stages, each of which corresponds to a certain level of decision-making. As the time interval between «today» and «planning point» decreases, more detailed information is used (Fig. 2). 


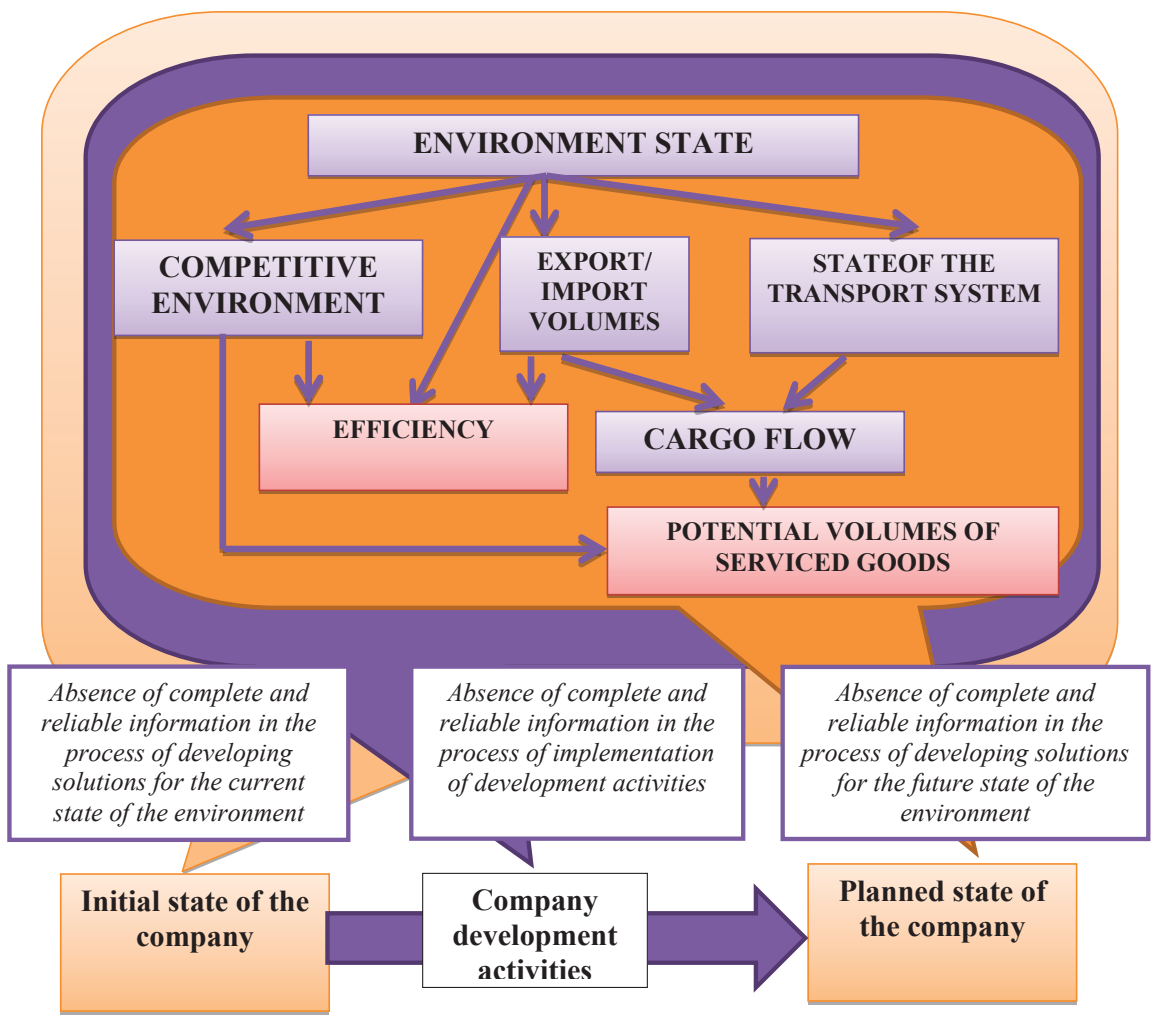

Fig. 1. Factors of uncertainty in the development of freight forwarding companies

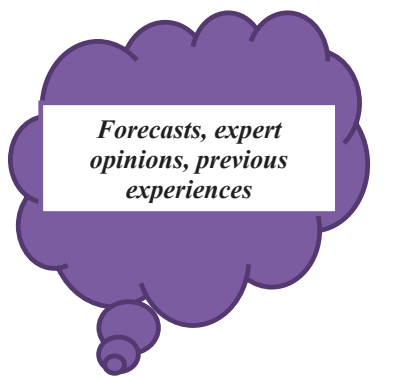

Time frame for choosing the development direction

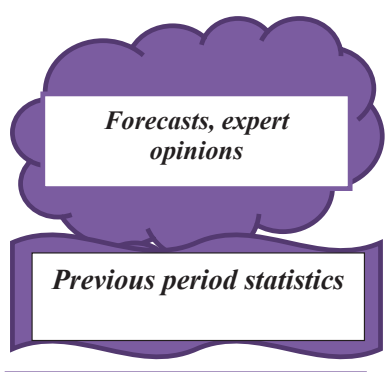

Time frame for development of the chosen development option

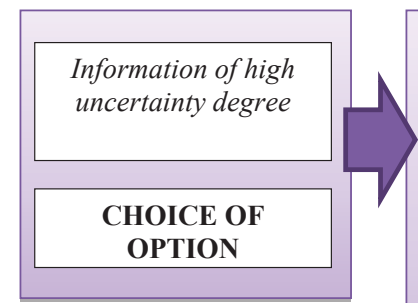

Information of two kinds: high uncertainty degree and statistical information

DEVELOPMENT OF PARAMETERS (DETAILIZATION) OF THE DEVELOPMENT OPTION

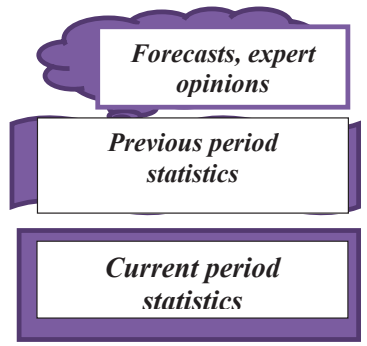

Time frame for the implementation of development activities

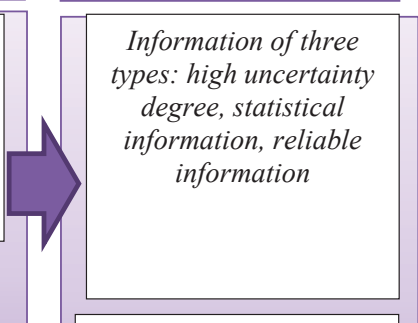

UPDATE OF THE PARAMETERS OF THE DEVELOPMENT OPTION

Fig. 2. Levels of information uncertainty at various stages of developing solutions for development of a freight forwarding company

At the stage of defining the concept of development, the uncertainty degree is the highest, the forecasts, opinions of experts and previous management experience serve as the main information base. The result of this stage is the choice of a variant of development from a set of alternatives based on aggregated information.
The next stage is the detailing of the chosen option formation of a system of parameters characterizing the development option taking into account the statistics of previous periods, which allows using statistical methods at this stage. When the development option begins to be implemented, the current information with a high relia- 
bility degree allows to adjust and refine the parameters of this development option.

Thus, the structure of information in terms of its uncertainty degree, changes as the horizon of planning of development activities decreases and the moment of their realization comes.

6.2. The method of substantiating the development option. In accordance with [18], let's briefly describe the procedure for multicriteria selection taking into account the proposed system of criteria that take into account the specific nature of freight forwarding companies.

It is required to form a set of characteristics of each development variant $X=\left\{X_{1}, X_{2}, \ldots, X_{k}\right\}$, corresponding to the system of criteria.

Let's denote $G=\left\{G_{1}, G_{2}, \ldots, G_{n}\right\}$ the set of quantitative and qualitative criteria by which variants $X=\left\{X_{1}, X_{2}, \ldots, X_{k}\right\}$ are evaluated, the set $\alpha=\left\{\alpha_{1}, \alpha_{2}, \ldots, \alpha_{n}\right\}$ - the weight of the importance of the criteria for which the condition must be met:

$$
\sum_{i=1}^{n} \alpha_{i}=1
$$

where $\alpha=\left\{\alpha_{1}, \alpha_{2}, \ldots, \alpha_{n}\right\}$ can be based on the opinions of experts.

For multicriteria analysis it is necessary to order the elements of the set $X=\left\{X_{1}, X_{2}, \ldots, X_{k}\right\}$ according to the criteria from the set $G=\left\{G_{1}, G_{2}, \ldots, G_{n}\right\}$. As a system of criteria forming the set $G$, let's propose the following (based on the above reasoning):

$G_{1}$ - necessary financial resources;

$G_{2}$ - change in the company's competitiveness;

$G_{3}$ - change in the company's market share;

$G_{4}$ - change in the financial result;

$G_{5}$ - period of the implementation of the direction;

$G_{6}$ - Priority of this direction for the company;

$G_{7}$ - degree of variant elaboration;

$G_{8}$ - risk degree of the option.

The advantage of the theory of fuzzy sets is that it allows to operate simultaneously both qualitative and quantitative criteria, taking into account their disequilibrium with the help of weights.

The task of multicriteria analysis consists in ordering the elements of the set $X$ by the criteria from the set $G$.

Let $\mu G_{i}\left(X_{j}\right) \in[0,1]$ - the degree of belonging of an element $X_{j}$ to a fuzzy set $\tilde{G}_{i}$ and characterize the evaluation level of the variant $X_{j} \in X$ by the criterion $G_{i} \in G$ : the larger the number $X_{j} \in X$, the higher the variant estimate by the criterion $G_{i} \in G, i=\overline{1, n} ; j=\overline{1, k}$.

Then the criterion $G_{i} \in G$ can be represented as a fuzzy set $\tilde{G}_{i}$ on the universal set of variants $X$ :

$$
\tilde{G}_{i}=\left\{\frac{\mu G_{i}\left(X_{1}\right)}{X_{1}}, \frac{\mu G_{i}\left(X_{2}\right)}{X_{2}}, \ldots, \frac{\mu G_{i}\left(X_{k}\right)}{X_{k}}\right\}
$$

Finding the degree of belonging of the fuzzy set (2) is proposed on the basis of paired comparisons according to the Saaty scale.

When using this method, it is necessary to form matrices of pairwise comparison of variants for each criterion, for example, for the criterion $G_{1}$ :

$$
\begin{aligned}
& \begin{array}{llll}
X_{1} & X_{2} & \ldots & X_{n},
\end{array} \\
& \left(G_{1}\right)=\begin{array}{l}
X_{1} \\
X_{2} \\
\ldots \\
X_{n}
\end{array}\left[\begin{array}{cccc}
1 & a_{12}^{1} & \ldots & a_{1 n}^{1} \\
a^{1}{ }_{21} & 1 & \ldots & a^{1} \\
\ldots & \ldots & 1 & \ldots \\
a_{n 1}^{1} & a^{1}{ }_{n 2} & \ldots & 1
\end{array}\right] .
\end{aligned}
$$

The total number of such matrices coincides with the number of criteria. Matrices of the form (3) are diagonal (on the diagonal -1 ) and inversely symmetric $a_{j s}^{i}=1 / a_{s j}^{i},(i=\overline{1, k}, j, s=\overline{1, n})$, that is. Elements of matrices are determined on Saaty ten-point scale:

1 - if there is no advantage of the element $X_{i}$ over the element $X_{i}$;

3 - if there is a weak advantage of $X_{i}$ over $X_{l}$;

5 - if there is a significant advantage of $X_{i}$ over $X_{l}$;

7 - if there is a clear advantage of $X_{i}$ over $X_{l}$;

9 - if there is an absolute advantage of $X_{i}$ over $X_{l}$;

2, 4, 6, 8 - intermediate comparative estimates.

The degree of belonging is defined as follows:

$$
\mu G_{i}\left(X_{j}\right)=\frac{1}{\sum_{j=1}^{n} a_{j s}^{i}}, i=\overline{1, k}, s=\overline{1, n} .
$$

A fuzzy solution $\tilde{D}$ is found by the rules of fuzzy mathematics as the criteria intersection:

$$
\begin{aligned}
& \tilde{D}=\tilde{G}_{1} \cap \tilde{G}_{2} \cap \ldots \cap \tilde{G}_{n}= \\
& =\left\{\frac{\min _{i=1, n}\left\{\mu G_{i}\left(X_{1}\right)\right\}}{X_{1}}, \frac{\min _{i=1, n}\left\{\mu G_{i}\left(X_{2}\right)\right\}}{X_{2}}, \ldots, \frac{\min _{i=1, n}\left\{\mu G_{i}\left(X_{k}\right)\right\}}{X_{k}}\right\} .
\end{aligned}
$$

Taking into account the non-equilibrium criteria:

$$
\begin{aligned}
& \tilde{D}=\tilde{G}_{1} \cap \tilde{G}_{2} \cap \ldots \cap \tilde{G}_{n}= \\
& =\left\{\begin{array}{l}
\frac{\min _{i=1, n}\left\{\left(\mu G_{i}\left(X_{1}\right)\right)^{\alpha_{i}}\right\}}{X_{1}}, \frac{\min _{i=1, n}\left\{\left(\mu G_{i}\left(X_{2}\right)\right)^{\alpha_{i}}\right\}}{X_{2}}, \ldots, \\
\frac{\min _{i=1, n}\left\{\left(\mu G_{i}\left(X_{k}\right)\right)^{\alpha_{i}}\right\}}{X_{k}}
\end{array}\right\} .
\end{aligned}
$$

The greatest advantage is the development option for which:

$$
\max \left\{\begin{array}{l}
\min _{i=1, n}\left\{\left(\mu G_{i}\left(X_{1}\right)\right)\right\}^{\alpha_{i}} ; \min _{i=1, n}\left\{\left(\mu G_{i}\left(X_{2}\right)\right)^{\alpha_{i}}\right\} ; \ldots ; \\
\min _{i=1, n}\left\{\left(\mu G_{i}\left(X_{k}\right)\right)^{\alpha_{i}}\right\}
\end{array}\right\} .
$$

The presented method makes it possible to carry out a multicriteria choice of the direction of development based on the theory of fuzzy sets with the formation of membership functions by the method of paired comparisons (Saaty).

6.3. Results of experimental calculations. The experimental calculations will be carried out for the following set of development options, formed on the basis of the method outlined in Table 1.

Weights of the criteria:

$\{0.2 ; 0.15 ; 0.1 ; 0.1 ; 0.05 ; 0.1 ; 0.15 ; 0.15\}$. 
Characteristics of the direction of development of the freight forwarding company, formulated on the basis of the morphological method

\begin{tabular}{|c|c|c|c|c|}
\hline Сipher and essence of direction/Values of criteria & $\begin{array}{l}\text { Development of cargo } \\
\text { traffic A } \\
\text { in region B, } X_{1}\end{array}$ & $\begin{array}{c}\text { Development of cargo } \\
\text { traffic B } \\
\text { in the region C, } X_{2}\end{array}$ & $\begin{array}{c}\text { Construction of } \\
\text { a warehouse } \\
\text { in region } B, X_{3}\end{array}$ & $\begin{array}{l}\text { Construction of } \\
\text { a warehouse } \\
\text { in region ᄃ ᄃ, } X_{4}\end{array}$ \\
\hline$G_{1}-$ necessary financial resources, thousand USD & 5 & 10 & 80 & 100 \\
\hline$G_{2}$ - change in the company's competitiveness & 0.1 & 0.2 & 0.25 & 0.3 \\
\hline$G_{3}$ - change in the company's market share & 0.05 & 0.05 & 0.1 & 0.1 \\
\hline$G_{4}$ - change in the financial result, thousand USD & 20 & 20 & 80 & 80 \\
\hline$G_{5}-$ period of the implementation of the direction, years & 0.5 & 0.5 & 1 & 1 \\
\hline$G_{6}-$ Priority of this direction for the company & 0.6 & 0.9 & 0.7 & 0.9 \\
\hline$G_{7}$ - degree of variant elaboration & 0.9 & 0.8 & 0.8 & 0.85 \\
\hline$G_{8}$ - risk degree of the option & 0.1 & 0.2 & 0.4 & 0.5 \\
\hline
\end{tabular}

Matrices of pairwise comparisons according to the Saaty scale:

$A\left(G_{1}\right)=\left(\begin{array}{cccc}1 & 1 / 3 & 1 / 7 & 1 / 9 \\ 3 & 1 & 1 / 5 & 1 / 7 \\ 7 & 5 & 1 & 1 / 3 \\ 9 & 7 & 3 & 1\end{array}\right), \quad A\left(G_{2}\right)=\left(\begin{array}{cccc}1 & 3 & 5 & 7 \\ 1 / 3 & 1 & 2 & 3 \\ 1 / 5 & 1 / 2 & 1 & 2 \\ 1 / 7 & 1 / 3 & 1 / 2 & 1\end{array}\right)$

$A\left(G_{3}\right)=\left(\begin{array}{cccc}1 & 1 & 3 & 3 \\ 1 & 1 & 3 & 3 \\ 1 / 3 & 1 / 3 & 1 & 1 \\ 1 / 3 & 1 / 3 & 1 & 1\end{array}\right), \quad A\left(G_{4}\right)=\left(\begin{array}{cccc}1 & 1 & 7 & 7 \\ 1 & 1 & 7 & 7 \\ 1 / 7 & 1 / 7 & 1 & 1 \\ 1 / 7 & 1 / 7 & 1 & 1\end{array}\right)$,

$A\left(G_{5}\right)=\left(\begin{array}{cccc}1 & 1 & 1 / 3 & 1 / 3 \\ 1 & 1 & 1 / 3 & 1 / 3 \\ 3 & 3 & 1 & 1 \\ 3 & 3 & 1 & 1\end{array}\right), \quad A\left(G_{6}\right)=\left(\begin{array}{cccc}1 & 5 & 3 & 5 \\ 1 / 5 & 1 & 1 / 3 & 1 \\ 1 / 3 & 3 & 1 & 3 \\ 1 / 5 & 1 & 1 / 3 & 1\end{array}\right)$,

$A\left(G_{7}\right)=\left(\begin{array}{cccc}1 & 1 / 3 & 1 / 3 & 1 / 2 \\ 3 & 1 & 1 & 1 / 2 \\ 3 & 1 & 1 & 2 \\ 2 & 2 & 1 / 2 & 1\end{array}\right), A\left(G_{8}\right)=\left(\begin{array}{cccc}1 & 1 / 3 & 1 / 5 & 1 / 7 \\ 3 & 1 & 5 & 5 \\ 5 & 1 / 5 & 1 & 1 / 3 \\ 7 & 1 / 5 & 3 & 1\end{array}\right)$.

By (4), let's find the degrees of membership and form sets without taking into account the weights of the criteria:

$$
\begin{aligned}
& \tilde{G}_{1}=\left\{\frac{0.05}{X_{1}}, \frac{0.075}{X_{2}}, \frac{0.23}{X_{3}}, \frac{0.63}{X_{4}}\right\}, \\
& \tilde{G}_{2}=\left\{\frac{0.6}{X_{1}}, \frac{0.2}{X_{2}}, \frac{0.12}{X_{3}}, \frac{0.08}{X_{4}}\right\}, \\
& \tilde{G}_{3}=\left\{\frac{0.38}{X_{1}}, \frac{0.38}{X_{2}}, \frac{0.125}{X_{3}}, \frac{0.125}{X_{4}}\right\}, \\
& \tilde{G}_{4}=\left\{\frac{0.44}{X_{1}}, \frac{0.44}{X_{2}}, \frac{0.06}{X_{3}}, \frac{0.06}{X_{4}}\right\}, \\
& \tilde{G}_{5}=\left\{\frac{0.125}{X_{1}}, \frac{0.125}{X_{2}}, \frac{0.38}{X_{3}}, \frac{0.38}{X_{4}}\right\}, \\
& \tilde{G}_{6}=\left\{\frac{0.58}{X_{1}}, \frac{0.1}{X_{2}}, \frac{0.21}{X_{3}}, \frac{0.1}{X_{4}}\right\},
\end{aligned}
$$

$\tilde{G}_{7}=\left\{\frac{0.11}{X_{1}}, \frac{0.23}{X_{2}}, \frac{0.35}{X_{3}}, \frac{0.25}{X_{4}}\right\}$,

$\tilde{G}_{8}=\left\{\frac{0.06}{X_{1}}, \frac{0.43}{X_{2}}, \frac{0.1}{X_{3}}, \frac{0.15}{X_{4}}\right\}$.

Taking into account the weights (components (6):

$$
\begin{aligned}
& \tilde{G}_{1}=\left\{\frac{(0.05)^{0.2}}{X_{1}}, \frac{(0.075)^{0.2}}{X_{2}}, \frac{(0.23)^{0.2}}{X_{3}}, \frac{(0.63)^{0.2}}{X_{4}}\right\}= \\
& =\left\{\frac{0.55}{X_{1}}, \frac{0.6}{X_{2}}, \frac{0.74}{X_{3}}, \frac{0.91}{X_{4}}\right\},
\end{aligned}
$$$$
\tilde{G}_{2}=\left\{\frac{(0.6)^{0.15}}{X_{1}}, \frac{(0.2)^{0.15}}{X_{2}}, \frac{(0.12)^{0.15}}{X_{3}}, \frac{(0.08)^{0.15}}{X_{4}}\right\}=
$$$$
=\left\{\frac{0.93}{X_{1}}, \frac{0.79}{X_{2}}, \frac{0.72}{X_{3}}, \frac{0.68}{X_{4}}\right\} \text {, }
$$$$
\tilde{G}_{3}=\left\{\frac{(0.38)^{0.1}}{X_{1}}, \frac{(0.38)^{0.1}}{X_{2}}, \frac{(0.125)^{0.1}}{X_{3}}, \frac{(0.125)^{0.1}}{X_{4}}\right\}=
$$$$
=\left\{\frac{0.9}{X_{1}}, \frac{0.9}{X_{2}}, \frac{0.81}{X_{3}}, \frac{0.81}{X_{4}}\right\} \text {, }
$$$$
\tilde{G}_{4}=\left\{\frac{(0.44)^{0.1}}{X_{1}}, \frac{(0.44)^{0.1}}{X_{2}}, \frac{(0.06)^{0.1}}{X_{3}}, \frac{(0.06)^{0.1}}{X_{4}}\right\}=
$$$$
=\left\{\frac{0.92}{X_{1}}, \frac{0.92}{X_{2}}, \frac{0.75}{X_{3}}, \frac{0.75}{X_{4}}\right\},
$$$$
\tilde{G}_{5}=\left\{\frac{(0.125)^{0.05}}{X_{1}}, \frac{(0.125)^{0.05}}{X_{2}}, \frac{(0.38)^{0.05}}{X_{3}}, \frac{(0.38)^{0.05}}{X_{4}}\right\}=
$$$$
=\left\{\frac{0.9}{X_{1}}, \frac{0.9}{X_{2}}, \frac{0.95}{X_{3}}, \frac{0.95}{X_{4}}\right\} \text {, }
$$$$
\tilde{G}_{6}=\left\{\frac{(0.58)^{0.1}}{X_{1}}, \frac{(0.1)^{0.1}}{X_{2}}, \frac{(0.21)^{0.1}}{X_{3}}, \frac{(0.1)^{0.1}}{X_{4}}\right\}=
$$$$
=\left\{\frac{0.95}{X_{1}}, \frac{0.79}{X_{2}}, \frac{0.85}{X_{3}}, \frac{0.79}{X_{4}}\right\} \text {, }
$$ 


$$
\begin{aligned}
& \tilde{G}_{7}=\left\{\frac{(0.11)^{0.15}}{X_{1}}, \frac{(0.23)^{0.15}}{X_{2}}, \frac{(0.35)^{0.15}}{X_{3}}, \frac{(0.25)^{0.15}}{X_{4}}\right\}= \\
& =\left\{\frac{0.72}{X_{1}}, \frac{0.8}{X_{2}}, \frac{0.85}{X_{3}}, \frac{0.81}{X_{4}}\right\}, \\
& \tilde{G}_{8}=\left\{\frac{(0.06)^{0.15}}{X_{1}}, \frac{(0.43)^{0.15}}{X_{2}}, \frac{(0.1)^{0.15}}{X_{3}}, \frac{(0.15)^{0.15}}{X_{4}}\right\}= \\
& =\left\{\frac{0.65}{X_{1}}, \frac{0.88}{X_{2}}, \frac{0.7}{X_{3}}, \frac{0.75}{X_{4}}\right\} .
\end{aligned}
$$

According to formula (6):

$$
\tilde{D}=\tilde{G}_{1} \cap \tilde{G}_{2} \cap \ldots \cap \tilde{G}_{n}=\left\{\frac{0.55}{X_{1}}, \frac{0.6}{X_{2}}, \frac{0.7}{X_{3}}, \frac{0.68}{X_{4}}\right\} .
$$

This allows to conclude that the third and fourth variants of development are superior over the first and the second, with the difference between the third and the fourth being insignificant (Fig. 3).

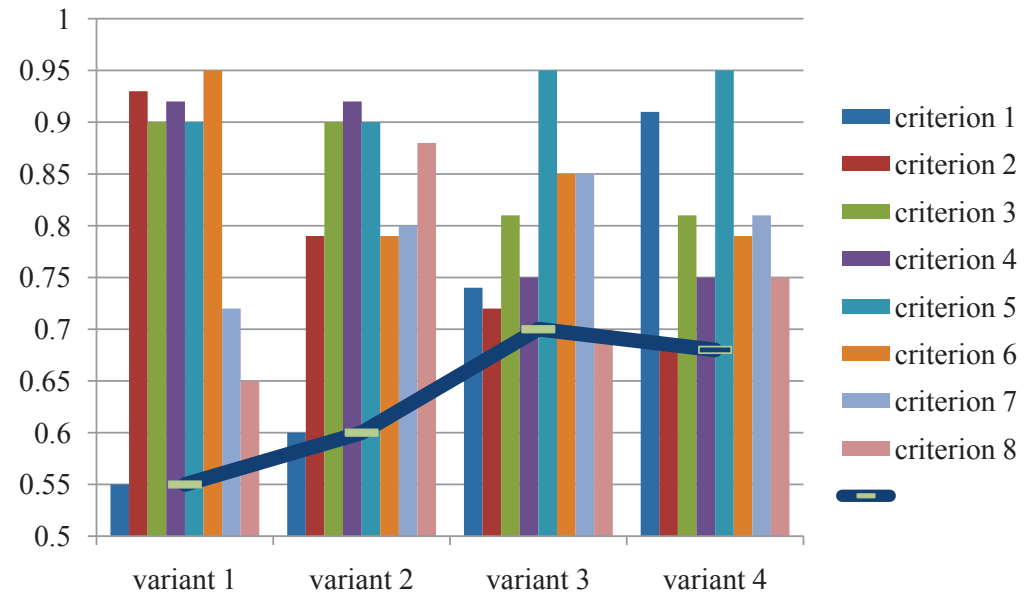

Fig. 3. Graphical interpretation of constructing the membership function of development options

Therefore, the final decision remains with the decisionmaker, taking into account additional information that was not taken into account by the criteria system, but allows for a final choice.

\section{SWOT analysis of research results}

Strengths. Among the strengths of this research, it should be noted that the method of substantiating the variant of the development of freight forwarding services for freight traffic has been further developed in terms of the scope of application. This method in the form of a combination of operations on fuzzy sets and Saaty pairwise comparison method is adapted to choose the direction of development of transport forwarding services by using a set of relevant criteria that extends the boundaries of the use of the known method.

Weaknesses. The weaknesses of this research are related to the unstable situation in the transport services market, and a great competition in the market of freight forwarding services. Political and economic factors play an important role in Ukraine, as a result, there is a decline in the volume of transport by various modes of transport.

Opportunities. The considered method takes into account the logic of practical implementation of the development processes of freight forwarding companies, which makes it possible to obtain a reliable result based on a set of criteria.

Threats. Threats in implementing the research findings are due to the fact that the complex of traditional freight forwarding services can be viewed from the perspective of quality and competitiveness. The necessary range of services, which is provided in modern conditions, requires its development to the required (reference) level. Therefore, when implementing the planned activities, the complexity manifests itself in two directions:

1) uncertainty of knowledge about the current state of the market and the company;

2) uncertainty of the future state of the external environment can't be completely and reliably described because of the large volume of influencing factors, and with the practical impossibility of their reliable prediction.

\section{Conclusions}

1. The main factors of uncertainty in the activity of freight forwarding companies are determined: the potential volumes of cargo for service, which are formed under the influence of a competitive environment, the volumes of foreign trade cargo and the state of the transport system.

2. A method for justifying the development of freight forwarding services for freight traffic under conditions of uncertainty has been developed. This method in the form of a combination of operations on fuzzy sets and Saaty pairwise comparison method is adapted to choose the direction of development of transport forwarding services by using a set of relevant criteria that extends the boundaries of the use of the known method.

3. Experimental calculations have been carried out, which confirm the reliability of the proposed method. The results of calculations from four variants of development have shown that the third and fourth development options have the greatest advantage, which obtained a maximum value of 0.70 and 0.68 with an insignificant difference. They received priority over the first and second development options, which make it possible the final choice when making a decision.

\section{References}

1. Gladkovska V. V. Etapy rozrobky rishen shchodo rozvytku transportno-ekspedytorskoi kompanii: proceedings // Problemy rozvytku transportnoi lohistyky Odessa, Batumi, Samsun: ONMU, 2018. P. 2-3

2. Ansoff H. I. Empirical proof of a paradigmic theory of strategic success behaviors of environment serving organizations // International Review of Strategic Management. 1993. Vol. 4 Part 9. P. 173-203.

3. Prahalad C. K., Hamel G. The Core Competence of the Corporation // Strategische Unternehmungsplanung/Strategische Unternehmungsführung. Physica-Verlag HD, 1997. P. 969-987. doi:10.1007/978-3-662-41482-8 46 
4. Zeithaml V. How Consumer Evaluation Processes Differ Between Goods and Services / ed. by Donnelly J. H., George W. R. // Marketing of Services. Chicago: American Marketing Association, 1981. P. 186-190.

5. Pride W. M., Ferrell O. C. Marketing. South-Western College Pub, 2008. 605 p.

6. Edvinsson L., Malone M. S. Intellectual Capital: Realizing Your Company's True Value by Finding Its Hidden Brainpower. New York: HarperBusiness, 1997. 240 p.

7. Crama Y., Pascual J. R., Torres A. Optimal procurement decisions in the presence of total quantity discounts and alternative product recipes // European Journal of Operational Research. 2004. Vol. 159, No. 2. P. 364-378. doi:10.1016/j.ejor.2003.08.021

8. Lobo A., Vivec J. Port users perspective of the container transshipment business // Proceedings of the International Conference on Port and Maritime R\&D and technology. Singapore, 2001. P. 87-94

9. Schnaars S. P. Marketing Strategy: Customers and Competition. New York: Free Press, 1998. 240 p.

10. A Dynamic Process Model of Service Quality: From Expectations to Behavioral Intentions / Boulding W. et al. // Journal of Marketing Research. 1993. Vol. 30, No. 1. P. 7-27. doi: $10.2307 / 3172510$

11. Kharchevska I., Onyshchenko S. Competitive environment analysis of forwarding companies in container transportation sector // Technology audit and production reserves. 2014. Vol. 6, No. 3 (20). P. 20-26. doi:10.15587/2312-8372.2014.31643

12. Nagornyy E. V., Naumov V. S. Razvitie i sovremennoe sostoyanie transportno-ekspeditsionnogo obsluzhivaniya predpriyatiy i organizatsiy v Ukraine // Vestnik KHNADU. 2009. Vol. 44 P. 63-67.

13. Naumov V. S. Otsenka riska vykhoda ekspeditora na rynok transportnykh uslug // Transportnye sistemy i tekhnologii perevozok. 2015. Vol. 10. P. 88-92.
14. Naumov V. S. Otsenka tselesoobraznosti raboty ekspeditora na rynke transportnykh uslug // Visnyk ekonomiky transportu i promyslovosti. 2009. Vol. 26. P. 114-117.

15. Venttsel E. S. Issledovanie operatsiy: zadachi, printsipy, metodologiya. Moscow: Nauka, 1988. 208 p.

16. Bellman R., Kalaba R., Zadeh L. Abstraction and pattern classification // Journal of Mathematical Analysis and Applications. 1966. Vol. 13, No. 1. P. 1-7. doi:10.1016/0022-247x(66)90071-0

17. Bellman R. E., Zadeh L. A. Decision-Making in a Fuzzy Environment // Management Science. 1970. Vol. 17, No. 4. P. 141-164. doi:10.1287/mnsc.17.4.b141

18. Rotshteyn A. P., Shtovba S. D. Nechetkiy mnogokriterial'nyy analiz variantov s primeneniem parnykh sravneniy // Izvestiya RAN. Teoriya i sistemy upravleniya. 2001. Vol. 3. P. 150-154.

ОБОСНОВАНИЕ ВАРИАНТА РАЗВИТИЯ ТРАНСПОРТНОЗКСПЕДИТОРСКОЙ КОМПАНИИ В УСЛОВИЯХ НЕОПРЕДЕЛЕННОСТИ

Идентифицированы факторы неопределенности в деятельности транспортно-экспедиторских компаний. Установлена поэтапная трансформация неопределенности в процессе реализации мероприятий по развитию. Существующий метод выбора в нечетких условиях адаптирован для обоснования варианта развития транспортно-экспедиторской компании. Установлено множество критериев выбора варианта развития. Представлены экспериментальные расчеты по выбору варианта развития комплекса услуг транспортно-экспедиторской компании.

ключевые слова: теория нечетких множеств, факторы неопределенности, развитие комплекса услуг транспортно-экспедиторской компании.

Gladkovska Valentyna, Postgraduate Student, Assistant, Department of Navigation and Maritime Safety, Odessa National Marine University, Ukraine, ORCID: http://orcid.org/0000-0003-4077-6711

\section{Stanovskyi O., Toropenko A., Lebedeva 0. Dohrovolska V., Daderko 0.

COMPENSATION OF THE SPATIAL
DEVIATIONS OF MEASURING
ELEMENTS IN CAD

Показано, що при вимірюваннях великогабаритних складних об'єктів іноді доводиться розташовувати частину елементів засобів вимірювання всередині об'єкта, а частину - зовні. В цьому випадку, особливо коли зовнішні елементи рухомі, можлива девіація останніх від запланованого розташування у просторі. Запропоновані методи, які здійснюють проектування засобів вимірювання таким чином, щоб вони адаптивно протидіяли таким явищам, що дозволяє знизити похибку вимірювання та підвищити його достовірність.

Ключові слова: елементи метрологічних засобів, просторова девіащія, автоматизоване проектування, похибка та достовірність вимірювань.

\section{Introduction}

The automated design of measuring instruments has certain features, which consist in the need to create additional favorable conditions for the operation of their sensitive organs. The fact is that the accuracy of the measuring instruments (MI) depends essentially on the stability of the geometric arrangement of their elements (EMI). And, although in EMI, as a rule, there are no significant mechanical strains, even minor deviations can lead to significant losses in positioning accuracy, and hence the accuracy and reliability of the results of such measurement.

Under the EMI deviation, static deformations or displacements, as well as dynamic oscillations or any combination of them, which are not envisaged in the passport geometric or kinematic scheme of the corresponding means, are understood in the work. 